1995

\title{
Law and the Myth of the Self in Mass Media Representations
}

Richard Sherwin

New York Law School, richard.sherwin@nyls.edu

Follow this and additional works at: https://digitalcommons.nyls.edu/fac_articles_chapters

\section{Recommended Citation}

Sherwin, Richard, "Law and the Myth of the Self in Mass Media Representations" (1995). Articles \& Chapters. 1198. https://digitalcommons.nyls.edu/fac_articles_chapters/1198 


\author{
LAW AND THE MY'TH OF THE SELF \\ IN MASS MEDIA REPRESENTATIONS
}

by

\author{
RICHARD K. SHERWIN* \\ New York Law School
}

One evening, not too long ago, I reopened Dante's Inferno. Seduced at first by the beauty of the text, I soon found myself outside looking in. I became a stranger to Dante's narrative world, cut off from its intricate network of eschatological symbols and social allusions. In my world, centuries away, Dante's profound faith has devolved into aesthetics. Far from Dante's luminous vision of meaning streaming into the mind from without, the advent of meaning today has become for the most part an affair of the mind alone.

The great American poet Wallace Stevens has written well of this twentieth century shift. In the narrative world of Stevens the passion for order may be no less than it has ever been, but its voice, the timbre of its call, has changed. Now we experience the ultimate contingency of order through the imagination. As Stevens succinctly wrote, "We say God and the imagination are one ..." 1

So pervasive has this experience of meaning's contingency become that it has even made a great hit in popular culture. It is popular because it is understood. It resonates deeply within our minds. You do not need to read Jacques Derrida. You can get it from the movies. Reality there can be read off the screen as the product of narrative construction. The film viewer can now simultaneously get the story and see its construction. In fact, these days, seeing the story's construction is often part of the story being told. Postmodernism has become fun, funny - a breeze.

An earlier version of this essay was presented in Toronto at the 1995 annual meeting of the Law \& Society Association. This material is adapted from a larger work in progress on the relationship between law and popular culture.

1. From "Final Soliloquy of the Interior Paramour", in Collected Poems of Wallace Stevens (New York: Vintage Press, 1959), 158. 
Take the American hit film Pulp Fiction. ${ }^{2}$ The characters come at you from out of a well-known narrative genre built up from familiar scenes and stereotypes: the thugs, the head honcho's moll, the free flowing drugs, the graphic violence. It's pulp. We all recognize it as such. Indeed, everything we see in the film is experienced as if it were wrapped in the thick gauze of that well-worn story type. The fun comes when the plot and character-types that we know so well drift in and out of our expectations, bringing those very expectations into view. The thugs are violent, and indifferent to the pain and death that they deal out, as thugs are prone to be. But they are also strangely self-aware, articulate - at turns philosophical and bizarre. These are characters who can quote scripture one moment and in the next lash out at a friend for soiling car upholstery with the blood of an innocent victim. ${ }^{3}$

These thugs are like gangster cartoon types anomalously equipped with wit, intelligence, and introspection. The mix is strange and amusing. When they become violent they do not lose their appeal. For we see their violence as part of the pulp genre with which we are already familiar. Viewing them through the lens that the genre provides insulates us from experiencing their violence as real. In fact, it's even comical. We get it: reality is a construct. It is made up of words and images that come to us from stories and character types that we know. The sense we make of what we hear and see depends on the context. We experience meaning through the narrative genres and stereotypes out of which words and actions are constructed. Meaning depends upon narrative framing. ${ }^{4}$

The law is no stranger to this postmodern ("constructivist") logic. For example, we need only recall that it is precisely this logic that enabled defence attorneys to reconstruct the meaning of video images that fortuitously captured white Los Angeles police officers beating black

\section{Miramax Films, 1993.}

3 As Philip Meyer has aptly observed, in Pulp Fiction film director Quentin Tarrantino "suggests a world where the only reality is an agglomeration of conversational fragments that allude to a shared pop culture iconography." See Philip Meyer, "Desperate for Love 2: Further Analysis of Cinematic Influences Upon Closing Arguments to a Jury in a Complex Criminal Case", (manuscript on file with the author).

4 I develop this theme further in a recent article. See Richard K. Sherwin, "Law Frames: Historical Truth and Narrative Necessity in a Criminal Case", Stanford Law Review 47 (1994), 39-83. 
motorist Rodney King. By shifting the context from police aggression to self-defence in the face of King's aggression, the defence altered the way the jury read the video. Newly digitalized images were choreographed at trial in synchrony with the defence theme. Police baton blows, slowed sufficiently to lose their violent edge, were now made to follow King's movements. The jurors' minds were able to fill in the causal connection: when King rose up, police blows followed. 5 Plainly, the police struck in reaction to King. He "controlled" the situation, argued the defence. And the jurors apparently agreed. They saw the police acting in selfdefence. ${ }^{6}$

The larger interpretive point being made here can be simply put. Seeing is believing, but reality lies in the eye of the beholder. Our beliefs help to create what we see. In this sense, Coleridge's notion of the reader's necessary "suspension of disbelief" can no longer be accepted as an accurate description of how we experience narrative truth. ${ }^{7}$ In fact it is just the reverse. Reality emerges out of belief: belief in the reality of character and plot set within a genre that generates its own discrete repertoire of readerly expectations. ${ }^{8}$

In short, belief comes first, and it comes from the story being told.

5 See Jerome Bruner, Actual Minds, Possible Worlds (Cambridge: Harvard University Press, 1986), 17: "An object moves toward another, makes contact with it, and the second object is seen to move in a compatible direction: we see causality."

6 See "The Police Verdict: Los Angeles Policemen Acquitted in Taped Beating", The New York Times, 30th April 1992, p.1, quoting a juror following the verdict: "The cops were simply doing what they'd been instructed to do. They were afraid [King] was going to run or even attack them."

7 See Richard J. Gerrig, Experiencing Narrative Worlds (New Haven: Yale University Press, 1993), 201-202: "The classic toggle image comes from Samuel Taylor Coleridge's Biograpica Literaria, in which he famously suggested that the experience of poetry requires a "willing suspension of disbelief." According to Gerrig (ibid.), "There is little evidence ... that readers can alter beliefs in any important sense by acts of will."

8 According to Gerrig (Ibid., at 230), "comprehension alone leads to belief in the veracity of a statement." See also Hayden White, Tropics of Discourse (Baltimore: John Hopkins University Press, 1978), 60: "[T]he historian must draw upon a fund of culturally provided mythoi in order to constitute the facts as figuring a story of a particular kind, just as he must appeal to that same fund of $m y$ tho $i$ in the minds of readers to endow his account of the past with the odour of meaning or significance." 
Disbelief will follow, if at all, only after we've taken the story in. Disbelief is harder than belief. It requires more effort. For disbelief to occur we must first critically confront what we already know, what we have already understood. As Spinoza recognized early on, understanding presupposes something already understood. ${ }^{9}$ We believe what we understand. When we step back from that understanding, subjecting what we know to critical reflection, perhaps then we may come to reject our knowledge as false. Or perhaps not, for it may be that we never come to suspend at least some of our narrative beliefs and expectations. In any event, it is these beliefs and expectations that shape and inform our sense of narrative truth. From these sources knowledge and understanding are made possible. ${ }^{10}$

Films like Pulp Fiction and trials like the Rodney King case are not the only evidence of a broad-based, popular understanding of the narrative construction of reality. We see it in a number of successful films and TV shows as well as in other popular trials. The Canadian film director Atom Egoyan expressed it well when he said in an interview about his most recent film, Exotica: "What's so exciting about film making [is] the way people piece together what they need ... to fill in their oun expectations." 11

I want to take up here this notion of making stories out of people's needs and expectations. My objective is to use this idea as a bridge that will take us from the narrative construction of reality in popular culture to its construction as a matter of law. For it is my claim that building stories out of people's needs and expectations is precisely what good American trial lawyers do in practice. The stories they tell in court tap into and hold on to jurors' pre-existing beliefs and expectations -

9. See Gerrig, supra n.7, at 227 , noting that, according to the Dutch philosopher Baruch Spinoza, "the acceptance of belief is an automatic concomitant of comprehension," and that the "unacceptance" of belief "may follow later, but the initial product of ordinary cognitive processing is a belief in the understood proposition." In short, before a stage of unacceptance, all information would be taken as true.

10 For further analysis of this proposition in the context of law, see Sherwin, "Law Frames", supra n.4.

11 See John Anderson, "A Filmmaker Who Plays With Expectations," New York Newsday B3 (7th March 1995). See generally Richard K. Sherwin, "The Narrative Construction of Legal Reality", Vermont Law Review 18 (1994), 681719. 
including their beliefs and expectations about what constitutes a good story and what kind of story plays best under what circumstances.

Of course for trial lawyers, unlike film makers perhaps, it is not simply a question of satisfying the audience's need for meaning or drama or catharsis. Trial lawyers need to stimulate in their audience the felt need for a particular kind of story. Which is another way of saying they have to activate the right set of expectations - the one that will win the case. ${ }^{12}$

Thus we may ask, what are the particular beliefs and expectations that particular legal story genres rely on?

Consider in this regard our expectations regarding that persistent, well-known and well-loved genre of storytelling known as the detective story. This kind of story typically features an investigator's ingenious, albeit straightforward, logic-driven marshalling of clues culminating in the discovery of objective truth. It is premised on an expectation of closure and finality. ${ }^{13}$ The detective story typically takes us along a causally sequential path ending with certainty, for in the end we know "who done it," who is to blame. Such knowledge is often accompanied by a sense of inevitability. As if to say, "If one were but to look at the

12 See, e.g., Michael E. Tigar, Examining Witnesses (Chicago: American Bar Association, 1993), 5: "People, including judges and jurors, understand and restate events in terms of stories. They take the available evidence and weave it into a coherent whole. If pieces are missing, they will fill in the gaps based on intuition, probability, or prejudgment ..."

13 See generally Sherwin, "Law Frames", supra n.4. All those litigators and jurors who at one time were beguiled viewers of that brilliant TV trial attorney, Perry Mason, know that in the final moment of artful cross-examination the confession will come and truth will dissolve any antecedent mystery. See remarks by Jeremiah Donovan in the "Lawyers as Storytellers Symposium" (transcript on file with Vermont Law Review). See also Tzvetan Todorov, Introduction to Poetics (Minneapolis: University of Minnesoata Press, 1981), 41 ("Most works of fiction of the past are organized according to an order that we may qualify as both temporal and logical; let us add at once that the logical relation we habitually think of is implication, or as we ordinarily say, causality."); Herbert Morris, "Decline of Guilt", Ethics 99 (1988), 62-76, at 69 ("Among law's clearest lessons are that norms exist and that they are to be taken seriously. These in turn provide reassurance that our social world is orderly and not chaotic. That it is a structured space in which not everything is permitted, where there are limits to conduct, a role for rational argumentation who has crossed these limits, and, equally important psychologically, that closure exists as a possibility once these limits have been breached."). 
matter closely enough, the truth shall emerge. It is but awaiting detection." 14 In this respect, the detective story may be said to represent a popular version of the long dominant "logico-scientific" genre. 15 The world according to this genre is one in which logic makes its demands and reality complies. Whether we desire it to be so or not is quite beside the point, for surely objective reality cares not a whit for human wishes and feelings. We must accept things as they are. We must accept what is. At least, that is the familiar posture in which one finds oneself when one is in the grip of this kind of explanatory narrative genre. In the logico-scientific detective story the audience is typically cast in the role of objective observer, with a view of reality that is both dispassionate and fixed. Faced with what has been shown to be the case, one accepts.

Prosecutors in criminal cases can be quite fond of this classically modernist story form. ${ }^{16}$ It comports nicely with their burden of proof, to demonstrate guilt beyond a reasonable doubt. And it carries a solid psychological insight. Cast into a world of objective truth, where deductive and inductive logic dictate concrete results, jurors may more readily accept their fate: to confirm what has already occurred, and to apply the rules that govern legal outcomes in such situations. Passivity before truth and law's mandate, letting the judgment that must come come, is a classic (although by no means exclusive) formula for prosecut -
orial success.

Consider, for example, the prosecution's closing arguments in the recent O.J. Simpson double murder case. Prosecutors Marcia Clark and Christopher Darden laid out a classic linear-causal, logic-driven

14

It may be that one of the great functions of the law is to propagate a continued belief in certitude and closure so that justice may be done. See Herbert Morris, supra n.13. This is, perhaps, the legal profession's own "noble lie", according to which the truth (of uncertainty) must be suppressed for the sake of a greater truth (the possibility of justice). On scapegoating, see generally René Girard, Violence and the Sacred (Baltimore: John Hopkins University
Press, 1977). 15 .

15 This is Bruner's term. See Actual Minds, supra n.5, at 12. Bruner also makes reference to the historical-causal sequence story. See also Bruner, "The Narrative Construction of Reality", Critical Inquiry 18 (Autumn 1991), 19, and Carlo Ginzburg, "Clues: Roots of an Evidential Paradigm", in Clues, Myths, and the Historical Method, ed. Carlo Ginzburg (Baltimore: John Hopkins University
Press, 1989), 106-117, referring to the Galilean method. 16 See Anthony G. Amsterdam and Randy Hertz, "An Analysis of Closing
Arguments to a Jury", New York Law School Law Review 37 (1992), 55-122. 
narrative. Theirs was a plea for "calm and reason". ${ }^{17}$ They implored the jury not to make any "quantum leaps in logic." 18 And they frequently contrasted the "fiery rhetoric" of the defence with their own reliance upon logic and reason. 19

For the prosecutors emotion was considered a distraction, anathema to the "objective" judgment that they were seeking from the jury. ${ }^{20}$ Logic was their watchword throughout the summations. And the final image with which they ended their address to the jury offers as fine an emblem of the logic-driven detective story as one is likely to find. It is the image of a jigsaw puzzle. There before the jury, projecting from an oversized television screen, are the pieces of the puzzle clicking into place. Each piece coincides with an element of the state's case: Simpson's opportunity to kill (click), his motive (click), the blood trail that he left at the scene of the crime (click), the victim's blood on his socks and glove (click), the victim's fibers on his knit cap (click), the actual glove that he wore during the murders (click), the personal style of the killing (click). Until, finally, all the pieces are in place, and there on the screen looms the completed picture: it is a picture of O.J. Simpson.

The jurors' task, therefore, is obvious: all they need to do is add up the pieces. Logic, in the face of objective reality, will dictate the result. Once the truth has emerged, the jurors have no choice: they must comply with the law's command.

Of course jurors may also be led to reject the classically passive role in which prosecutors often cast them. Rather than being ruled by fixity (being bound by manifest reality) and closure (following the law's mandate), jurors may instead be induced to enter a world of dramatic possibility and openness. At any rate, there is a good chance that this is the kind of world that the defence's story will seek to conjure. ${ }^{21}$ This type of story lacks logico-scientific precision. Instead, it depicts a world filled with contingencies, uncertainties, the stuff of human drama. The world that it presupposes is psychologically in process, what cognitive

17 See trial transcript, 27th September 1995, at 248. All references to the attorneys' summations in the Simpson case were obtained from the Lexis-Nexis service's "unedited and non-certified" transcript of the trial.

18 Ibid.

19 Ibid., at 50 .

20 Ibid., at 68.

21 See Amsterdam and Hertz, supra n.16. 
psychologist Jerome Bruner calls subjunctivized reality. ${ }^{22}$ In such a world, jurors are likely to feel compelled to rely upon their own world knowledge in order to fill in gaps that the defence story leaves open. They will also reach into their own stock of emotional resources to animate the story being told. The jurors' inherited cultural knowledge and emotional repertoire will be deliberately triggered by the familiar images, stock scripts, and predictable scenarios that defence counsel uses during the course of the trial, particularly during the opening and closing statements to the jury. The jurors' investment of their own knowledge and emotional energy will also serve as an additional source of authority for the story in which they are investing. For how can they quarrel with what their own life experience tells them about the world? 23

In direct contrast then to the prosecution's passivity-inducing, logicdriven ("detection") narrative, the defence wants the jurors to know that this is their story too. They have the final say in how the case shall be resolved. Nothing is necessitated from without: neither by objective reality, nor by some impersonal ("logical") force. ${ }^{24}$ Instead, it is now the

22

See Bruner, supra n.5, at 25-26, referring to subjunctification as "the depiction of reality not through an omniscient eye that views a timeless reality, but through the filter of consciousness of the protagonists in the story.") According to Bruner (at 26), "To be in the subjunctive mode is, then, to be trafficking in human possibilities rather than in settled certainties."

It is important to note that while Bruner seems quite right to distinguish "a good story" from "a well-formed argument", especially with respect to their respective procedures for verification, in legal practice argument and storytelling often share a complex set of interactions. For example, a story at trial can tell jurors how to use argument in a given case. A fuller analysis of this complex process, however, would take us well beyond the scope of this essay. See William Twining, "Anchored Narratives - A Comment", European Journal of Crime, Criminal Law and Criminal Justice 1 (1995), 106-114, at 111 (astutely noting the need, in the context of advocacy and adjudication, to clarify the respective roles of stories and arguments in the theory of evidence).

23 See Gerrig, supra n.7, at 13 , noting that according to the principle of "minimal departure" people reconstrue fictional narrative worlds as being the closest possible to the reality that they know. This means that we tend to project upon the world of the statement everything we know about the real world, and that we will make only those adjustments which we cannot avoid. 24

Compare, for example, Justice Blackmun's empathic and emotional narrative, in his dissent in DeShaney v. Winnebago County Department of Social Services, 489 U.S. 189 (1989), with Justice Rehnquist's imperative, syllogistic interpretation of relevant case law. According to Justice Rehnquist: "[N]othing 
jurors themselves who are empowered to realize the kind of self and social reality that the defence narrative holds out. It is up to them, however, to seize the possibility of becoming, by their own action (i.e., by "doing the right thing"), the heroes they aspire to be in a world of values they wish to affirm.

The O.J. Simpson trial provides an excellent illustration of the dramatic hero role that the defence often will assign to jurors. Notably, in the Simpson defence's view, the jury decisionmaking process is not a simple matter of passive fact detection or a matter of simply gazing back into the past. It is far more active, more present and future-oriented, than that. To be sure, it is not the simple task that prosecutor Christopher Darden had in mind for the jurors when he told them: "This case really is a simple case when you get down to the bottom line ... [A]ll you have to do is use your common sense." 25 Indeed, it turns out that within the heroic genre being tapped by the defence, the jurors themselves are among the main protagonists in a story that is unfolding in real time within the courtroom itself. ${ }^{26}$ As defence counsel Johnny Cochran repeatedly put it, the jurors are on "a journey toward justice", 27 and it is they who will determine what destination will be reached by trial's end.

This is no ordinary voyage. It is a heroic quest. As the defence notes, others have joined in this quest, such as Frederick Douglas, over a hundred years ago, who fought as a former slave against the evils of slavery and racism in America. ${ }^{28}$ These are the jurors' forebears and comrades in the heroic struggle against what Cochran repeatedly referred to at trial as "genocidal racism" - a phrase that Cochran used in

in the Due Process Clause of the Fourteenth Amendment requires the State to protect the life, liberty, and property of its citizens against invasion by private actors." In contrast, Justice Blackmun states: "Poor Joshua! Victim of repeated attacks by an irresponsible, bullying, cowardly, and intemperate father, and abandoned by respondents who placed him in a dangerous predicament and who knew or learned what was going on, and yet did essentially nothing except, as this Court revealingly observes, ante, at 193, 'dutifully recorded these incidents in [their] files."

25 See trial transcript at 221.

26 See Amsterdam and Hertz, supra n.16.

27 See trial transcript at 68 .

28 See trial transcript at 82 . 
particular to describe the views of the state's star witness, Los Angeles police officer Mark Fuhrman. Fuhrman's overtly racist views toward blacks and mixed race couples were an important part of the defence's evidentiary record at trial. Indeed, Fuhrman himself came to symbolize the official corruption and abuse of power that targeted the defendant in the first place. ${ }^{29}$

It is from this diverse cast of allies and enemies that the jurors were to gauge their own self-identity and moral stature in the struggle taking place in court, and in the nation at large. For as the defence repeatedly reminded them, these jurors, and perhaps they alone, were empowered to change the current state of affairs in the country. It was up to them to undo the injustices stemming from state racism and abuse of power - if the jurors had the courage and the fortitude to realize their ideals and principles. ${ }^{30}$ As Cochran exhorted during his summation:

29 Throughout the defence team's opening arguments, the state was condemned for its "rush to judgment". According to the defence, the state "targeted" O.J. Simpson without pursuing any other possible suspects. The prosecutors and the Los Angeles police department were swept into the defence's story of a quasi-conspiratorial, race-based "scapegoating" of Simpson. Much could, and no doubt will, be said about the Simpson defence team's manipulation of juror anger against the state and the strategy of triggering anger as a way of eclipsing the jurors' reliance on fact-based, truth-oriented argumentation. The defence objective apparently was to defuse, or bypass altogether, if possible, the jurors' tension-filled task of repudiating O.J. Simpson qua local folk hero. To accomplish this would require substituting such an unpleasant task with a more personally uplifting one, namely: the task of fulfilling a higher form of (symbolic) justice. In short, for the sake of a larger, case-transcending goal - justice in a society riven by racism and official corruption - the jurors could avoid the cognitive dissonance that would stem from tearing down a widely admired figure. Adopting the defence perspective, jurors could actually preserve Simpson's heroic identity, or at least the jurors' experience of identifying with the heroic values that Simpson might personally embody for them, by displacing that sense of heroism onto others. In this instance, those others turned out to be defence lawyer Johnny Cochran and the jurors themselves. The task of mourning the loss of the fallen idol could thus be avoided.

30 This is not the only time lawyers have placed jurors in a grandiose role. See, e.g., Laura Hanft Korobkin, "The Maintenance of Mutual Confidence: Sentimental Strategies at the Adultery Trial of Henry Ward Beecher", Yale Journal of Law and the Humanities 7 (Winter 1995), 1-48, at 16, noting that jurors at this infamous trial, which stretched on from 1874 through 1875 , were told that their deepest personal, cultural, and religious values were somehow at 
"You are empowered to say we are not going to take [police abuse of power and racism] anymore ... You have the authority ... Please don't compromise your principles ... don't rush to judgment. Don't compound what [the state has] already done in this case." 31

In short, it was up to the jury, by their judgment in this particular case, to set justice straight. The state's abuses - their reliance upon racist police officers like Mark Fuhrman and their proffering of tainted evidence in court - could only be checked by the jurors' heroic action. Surely this is a far cry from the passive role that the state would have the jurors play. To fulfil the defence's challenge would require principled commitment. The jurors must ask themselves: "Was I naive? Was I timid? Or was I courageous? Did I believe in the Constitution? Did I believe in justice? Did I do my part for integrity and honesty?" 32 Notably, it is only by a verdict of acquittal that the jurors can realize the heroic identity that the defence holds out for them. As Johnny Cochran put it: "In a society where many people are apathetic" 33 it is up to the jurors to act: "You are the ones who made a commitment, a commit ment toward justice, but you got to see it through ... If you don't stop it [i.e., the state's cover-up] then who? Do you think the police depart ment is going to stop it? Do you think we can stop it by ourselves? It has to be stopped by you ... You police the police through your verdict ... You are the ones in war, you are the ones who are on the front line ..." 34

Thus do we see the defence wrapping the jurors into an encompassing heroic drama in which they too serve as protagonists. It is a drama that began long before O.J. Simpson was unfairly targeted by racist police officers. And it is a drama that continues to unfold at trial. In short, the drama being narrated by the defence involves the defendant,

stake in the courtroom and that "strangers from distant climes" would one day make pilgrimages to the courtroom to see the place "from which was given back to the world freed from cloud or passing shadow, the name of Henry Ward Beecher.". Compare Johnny Cochran's words to the Simpson jury: "Your verdict in this case will go far beyond the walls of department 103 because your verdict talks about justice in America." Transcript at 47.

31 28th September 1995, transcript at 75.

32 Ibid., at 68.

33 Ibid., at 74 .

34 Ibid., at 76 . 
but it also goes well beyond him. Indeed, according to the defence's narrative, the jurors as well must confront the same evils and dangers presented by a racist state. What is more, only they have the power to save themselves along with O.J. Simpson and other oppressed minorities from this kind of official abuse of power.

In the end, according to the Simpson defence team's narrative, the mystery underlying the deaths of Nicole Brown Simpson and Ron Goldman may remain, which is to say that the truth may not have been detected after all. But in the defence view, this is no cause for regret. For there is, they suggest, an even greater prize to be won than truth. It is the prize of justice. By this reasoning, the defence comes close to inviting the jury not only not to obey, but actually to nullify the law's command. ${ }^{35}$ For to do otherwise would be to participate in the state's own corrupted processes. ${ }^{36}$ As to the uncertainty this leaves with respect

35

Compare Alexander Hamilton's closing argument to the jury in the 1735 libel trial of John Peter Zenger:

The power is in your hands, gentlemen, to safeguard our liberties. If you should be of the opinion that there is no falsehood in Mr. Zenger's papers, you will, nay, you ought to say so ... [You must] support liberty, the only bulwark against lawless power. Nature and the laws of our country have given us a right - the liberty - both of exposing arbitrary power ... by speaking and writing truth.

(cited in William Kunstler, My Life as a Radical Lawyer (New York: Carol Publishers, 1994), 191), with Johnny Cochran's closing argument in the Simpson case:

Now, it is your time to perform ... We are going to watch you work and watching you work is what makes this country so great. Because it is twelve citizens good and true coming together from this community from disparate backgrounds, experience not required, citizenship, the only requirement to do justice, to do right, to right some wrongs, to straighten
this out ...

(28th September 1995, transcript at 23).

36 As Johnny Cochran told the jurors in his closing argument: "You and I, fighting for freedom and ideals and for justice for all, must continue to fight to expose hate and genocidal racism and these tendencies. We then become the guardians of the Constitution ..." (ibid., at 182).

Ironically, a similar rationale may be found in the Supreme Court's constitutional jusitification for precluding even truthful evidence from trial if it has been obtained in violation of due process. The difference is that in the Simpson case we have an example of bottom-up ("popular") constitutionalism, rather than the high court's top-down authorization of process values over truth values. Compare Rogers v. Richmond, 365 U.S. 534 (1961) (opposing 
to truth (who done it?) this may be overcome by closure of a different sort. It is the closure that comes with the heroic affirmation of what is right, acting for a greater good, a higher value or ideal than truth. It comes with doing justice. In sum, for the Simpson defence to have its way, the prosecution's mystery genre ("find the truth!") must be trumped by the heroic genre ("do justice?").

Of course each side is right, albeit each in its own way. For what is a trial, at least in the Anglo-American common law tradition, but a contest between conflicting narrative accounts, including conflicting genres, story lines, and character types? ${ }^{37}$ Because the stakes at trial are high the temptation is strong to objectivize truth. The more subjective one's judgment the greater one's sense of responsibility. And the greater one's sense of personal responsibility the greater is the weight of individual decisionmaking. If that responsibility can be made to ride upon the shoulders of what truth and law demand it follows that the weight on the individual juror-decisionmaker will be lessened. After all, it is simply "the Truth" or "what law demands" that is at stake. What can one do? The decisionmaker's hands are tied. The burden lies elsewhere.

Trial lawyers know how to play off of jurors' sensitivity to the responsibilities of decisionmaking. Prosecutors with a "just the facts, ma'am" storytelling style ${ }^{38}$ typically strive to objectify reality and make judgment passive (asking jurors to "discover" the truth and obey the law's mandate), in order to minimize the juror's burden. But this strategy also carries a price. It risks telling a legal story that falls flat in court. Prosecutors in the recent Rodney King and O.J. Simpson cases ended up paying that price. Unlike the historically accurate, but

convictions based on coerced confessions - not because the confessions thus obtained were untrue, but because "the methods used to extract them offend an underlying principle in the enforcement of criminal law: that ours is an accusatorial and not an inquisitorial system.") with Robert Cover, "The Bonds of Constitutional Interpretation: Of the Word, the Deed, and the Role", Georgia Law Review 20 (1986), 815-833, at 832-33 ("The citizen or dissenter's constitutional interpretation cannot be less the deed than that of the state's officials. If the officials of the state realize their vision in blood, the dissenter must also either suffer or impose a parallel form of violence.").

37 See Sherwin, "The Narrative Construction of Legal Reality", supra n.11.

38 See Kim Lane Scheppele, "Just the Facts, Ma'am: Sexualized Violence, Evidentiary Habits, and the Revision of Truth", New York Law School Law Review 37 (1992), 123-172. 
dramatically weak "chronicle" genre, the defence more often seeks actively to engage the jurors in a heroic drama. By inviting such a participatory stance toward events and cultural themes that are being played out in court, the defence may shift the jurors' focus. Instead of uncovering "objective" truth and "dispassionately" (or logically) applying to it the law's command, jurors may now be more apt to probe the underlying motives and intent of the accused. There is also greater incentive to go beyond the surface of events, to see a larger social and cultural canvas - including the kind of self and social reality that one may create by opting for one particular narrative construction rather than another. Of course the characteristic danger for the defence in this effort is that their drama may be overplayed. When that happens, the drama falls upon the courtroom stage as deflated, empty rhetoric.

The specific legal stories that I discuss more fully in what follows will, I hope, make plain the complex inter-connection between law and popular storytelling. While this cross-fertilization between legal and popular culture is certainly not a new phenomenon, ${ }^{39} \mathrm{I}$ believe that it has become more prominent in recent years due to the profound impact of visual mass media, particularly film and television, on the way that we see and think about ourselves, others, and the world around us.

Mass media stories connect up with the law in at least two different ways. First, trial lawyers often draw upon familiar mass media stories in order to tap into popular notions about the way things and people are in the world. As a couple of clever advertising executives once said: "To be successful today, you must touch base with reality. And the reality that really counts is what's already in the prospect's mind." 40 Since a good deal of what fills people's heads these days comes from the mass media - from newspapers, magazines, film, and television - it is not surprising to find lawyers drawing stories from these sources.

In addition to using mass media stories to work off of a jury's preexisting beliefs and expectations, however, there is at least one other use.

39 For examples of notorious, highly "mediatized" trials from the last century, see Andie Tucher, Froth and Scum: Truth, Beauty, Goodness, and the Ax Murder in America's First Mass Medium (Chapel Hill: University of North Carolina Press, 1994); Robert Ferguson, "Story and Transcription in the Trial of John Brown", Yale Journal of Law \& the Humanities 6 (1994), 37-73; Korobkin, supra n.30.

40 Al Ries and Jack Trout, Positioning: The Battle for Your Mind (New York: McGraw-Hill, 1986, rev'd ed.), 5. 
Lawyers also tap into mass media stories for external consumption, going beyond the courtroom. For example, trial lawyers may seek to emulate the way in which mass media stories are told so that the lawyer's story can be quickly told again by the mass media. In this way, trial lawyers may reinforce their message with the added weight of the electronic medium to which their message has been adapted. This is not simply a matter of skirting the storytelling constraints of trial by going public. It is also a matter of translating one's message into a medium of choice. For example, in the case of television, this means deliberately creating captivating visuals and snappy sound bites. ${ }^{41}$

This external use of mass media is often exploited by lawyers handling political cases, or cases that they would like to be regarded as political cases. Here the public is often used as a kind of "meta-jury" to keep tabs on the trial itself. Since the violent aftermath of the first Rodney King trial, this external use of media stories has become rather familiar. Few American TV viewers (which means few Americans) will soon forget the mass rioting that erupted in central Los Angeles after twelve Simi valley jurors acquitted the officers accused of assaulting Rodney King. Nor will they forget the outcome of the Reginald Denny trial that followed shortly thereafter. The Denny case involved a violent assault captured live by a television news camera. The images graphically showed a black defendant beating white motorist Denny on the head, at one point with the aid of a brick. As in the Rodney King case, these explicit images also failed to secure a conviction. ${ }^{42}$

At the Denny trial, the defendant claimed, successfully, that he had been caught up in the spirit of the rioting that erupted in response to the acquittal of the Los Angeles police officers in the King case. The pall of racial injustice that hung over the city, and the nation, following the King verdict was palpable. The Denny verdict was perhaps a way for citizens to lift that shroud (what others might call "evening the score"). In any event, this outcome suggests what those in the mass media already know: video images are not objective sources of knowledge about

41 Consider in this regard Johnny Cochran's battery of easy-to-retain slogans in his summation at the Simpson trial: "Be fair. Don't be a part of this continuing cover-up. Do the right thing, remembering that if it doesn't fit, you must acquit, that if these messengers have lied to you, you can't trust their message" (29th September 1995, transcript at 39).

42 It is interesting to note that Simpson defence attorney Johnny Cochran also represented the defendant in the Reginald Denny case. 
the world. ${ }^{43}$ The Denny case outcome also suggests that the judgment of jurors in highly publicized cases, like the King, Denny, and Simpson cases, is likely to enter into the domain of larger public issues. As a result, these jurors are unlikely to be indifferent to the mass media's framing of the issues involved. From this perspective, it is hardly surprising to hear echoes of the King case, and concomitantly the threat of a similarly violent aftermath, resonate within Johnny Cochran's defence summation in the O.J. Simpson case. ${ }^{44}$

In the remaining part of this essay I wish to illustrate internal (incourt) and external (out-of-court) uses of mass media representations. I will do so by drawing upon two well-known American criminal trials. First, the 1969 trial of the Chicago Seven: a case involving defendants who were indicted for crossing state lines with the intention of causing a riot. By way of context-setting, at the time of their arrest, 1968, in Chicago, the Democratic party's presidential convention was under way. The acrimonious divisions inside the convention hall were mirrored on the streets of the city. This was, after all, a time when the Vietnam war was splitting the country into two increasingly hostile opposing camps.

The second trial that I want to discuss took place in 1977. This case involved capital murder charges against Randall Dale Adams for shooting a Dallas police officer. Adams was convicted and sentenced to death in the electric chair, but ultimately freed in the aftermath of an alleged "documentary" film ${ }^{45}$ which persuasively established that Adams had been framed.

Both of these trials demonstrate the deliberate and calculated use of mass media representations to construct legal realities, including the reality of self. In both cases we see stock scripts, familiar story lines, and classic character types being lifted from pop cultural narratives and purveyed inside the courtroom for consumption by the jury. We also see similar pop narrative representations being purveyed from inside the

43 See Charles Hagen, "The Power of a Video Image Depends on the Caption", The New York Times, 10th May 1992, 32, noting that "photographic images of all sorts remain essentially ambiguous, and must be anchored in a convincing narrative before they take on a specific meaning" and that "most images can be made to fit into a number of widely disparate narratives."

44 See, e.g., Johnny Cochran's comment in closing argument: "Thank heaven we have videotape ... [W] know in this city how important videotapes can be when people don't want to believe things ..." (Trial transcript at 178).

45 Errol Morris's The Thin Blue Line (Third Floor Productions, 1988). 
courtroom to the world outside through the mass media, for consumption by the public at large.

The specific questions I want to address are: How were mass media stories used in these cases to construct the identity of the protagonists at trial? And how did the emulation of mass media storytelling techniques - for example, the deliberate use of mass media story bites - shape the public's understanding of these trials and of the reality that they depicted?

\section{The Chicago Seven Trial}

Defendant Tom Hayden wrote of the trial: "Our crime was our identity ... The vague nature of the government's case made us feel we were on trial for something deeper and unspoken." 46 In response, the defence used techniques of self-dramatization and counter-cultural mythification to dramatize its case. In effect, the trial became theatre: with the prosecutors and judge cast as fossilized, arbitrary, and violent agents of the state, while the defendants were to appear as lively, playful, and erotic free spirits. The defence team mobilized for the trial the icons of pop culture. Singers Arlo Guthrie, Judy Collins, and Pete Seeger testified, as did writers Allen Ginsberg, William Burroughs, and Norman Mailer.

The defendants' dress and antics and discourse throughout the trial also replicated countercultural images and stories of identity. For example, here is defendant Abbie Hoffman taking the witness stand:

Mr. Weinglass:

The Witness:

Mr. Weinglass:

The Witness:

Mr. Weinglass:

The Witness:

The Court:

The Witness:
Will you please identify yourself for the record?

My name is Abbie. I am an orphan of America.

Where do you reside?

I live in Woodstock Nation.

Will you tell the Court and jury where it is?

Yes. It is nation of alienated young people. We carry it around with us as a state of mind in the same way as the Sioux Indians carried the Sioux nation around with them.

Just where it is, that is all.

It is in my mind and in the minds of my brothers

46 Tom Hayden, Trial (New York: Holt, Rinehart \& Winston, 1970), 29. 
and sisters.

The Court:

No, we want the place of residence in what state is Woodstock?

The Witness:

It is in the state of mind. ${ }^{47}$

Playfulness and surrealist humour permeate the trial transcript. For example, consider this exchange in court:

The Court:

The Witness:

Kunstler:

The Court:

The Court:

Mr. Rennie Davis:
The remarks of the witness may go out and the jury is directed to disregard them.

Where do they go when they go out? ${ }^{28}$

Your Honour, if I could make one application the other seven defendants have purchased a birthday cake for Chairman Bobby Seale.

Mr. Kunstler, I won't even let anybody bring me a birthday cake.

Your application will be denied.

They arrested your cake, Bobby. They arrested it. $^{49}$

Ass't U.S. Atty. Schultz: If the Court please, I would ask the Court again if he would direct the marshals to direct the defendants and their lawyers to stop laughing out loud.

Kunstler:

But your Honour, we are human beings, too. You can't make automatons out of us, or robots; we are human beings and we laugh occasionally, and if it come irrepressibly, I don't really see how that really becomes a court matter.

Mr. Schultz: jury with the impression that this is absurd.

47 The Conspiracy Trial [hereinafter "transcript"] (ed. by Judy Clavir and John Spitzer) (New York: Bobbs Merrill, 1970), 344 (testimony of defendant Abbie Hoffman).

48 Transcript at 349 [testimony of defendant Abbie Hoffman].

49 Transcript at 122 [testimony of defendant Rennie Davis]. 
That is why he is laughing aloud. ${ }^{50}$

The Witness:

I want to comply with Mr. Schultz's request to do a head stand in court, if he wants to see me do it. I think it might start a riot. ${ }^{51}$

And when goaded into playing its contrasting "authoritarian" role, the state complied. Consider, for example, Judge Julius Hoffman's orders that defendant Bobby Seale (then chairman of the militant Black Panther party) be gagged and bound to his chair inside the courtroom:

Mr. Tom Hayden:

Now they are going to beat him, they are going to beat him.

Abbie Hoffman:

You may as well kill him if you are going to gag him. It seems that way, doesn't it?

The Court: You are not permitted to address the Court, Mr. Hoffman. You have a lawyer.

Abbie Hoffman: This isn't a court. This is a neon oven.

Ass't U.S. Atty. Foran: That was the defendant Hoffman who spoke.

Ass't U.S. Atty. Schultz: Prior to that it was Mr. Hayden who was addressing the jury while they were walking out of here.

Mr. Tom Hayden:

I was not addressing the jury. I was trying to protect Mr. Seale. A man is supposed to be silent when he sees another man's nose being smashed?

Abbie Hoffman: The disruption started when these guys got into overkill. It is the same thing as last year in Chicago, the same exact thing. ${ }^{.2}$

Mr. Dellinger:

There's no pretence of fairness in this court. All you're doing is employing a riot - employing force and violence to try to keep me quiet. Just like you gagged Bobby Seale because you

50 Transcript at 207 [in-court statement by defence attorney William Kunstler].

51 Transcript at 371 [testimony of defendant Abbie Hoffman].

52 Transcript at 169 [in-court statement by defendant Abbie Hoffman]. 
Marshal Joneson:

Mr. Dellinger: couldn't afford to listen to the truth that he was saying to you. You're accusing me. I'm a pacifist.

Sit down, please, and be quiet.

I am employing nonviolence, and you're accusing me of violence, and you have a man right here, backed up by guns, jails, and force and violence. That is the difference between us. ${ }^{53}$

The state's efforts to discredit the counterculture's embrace of overt sexuality made particularly vivid the split between the parties. For example, on cross-examination the prosecutor takes American Beat poet Allen Ginsberg to task for an explicit reference in one of his poems to homosexual love. The poem begins with a line from Walt Whitman: "I'll go into the bedroom silently and lie down between the bridegroom and the bride/those bodies fallen from heaven stretched out waiting naked and restless..." 54

There can be little doubt that the state was seeking here to taint the defendants in the eyes of the jury by provoking a homophobic response to Whitman's and Ginsberg's poetry. For their part, the defence had Ginsberg recite the opening lines from his great 1956 poem, "Howl": "I saw the best minds of my generation destroyed by madness ..." 55

By the time Ginsberg leaves the stand we see the defendants moved to tears, and we hear the prosecutor mutter, "Damn fag". 56

According to Tom Hayden, co-defendants Abbie Hoffman and Jerry Rubin "wanted to create the image of a courtroom in shambles ... Part of the Yippie genius is to manipulate the fact that the media will always

53 Transcript at 468 [testimony of defendant Dave Dellinger]. See Tom Hayden, Trial, supra n.46, at 49: "Putting our identity on trial caused our prosecutors to expose their own."

54 Transcript at 305-306 (quoting a line from Whitman in Ginsberg's poem, "Love Poem on Theme by Whitman").

55 See Hayden, Trial, supra n.46, at 38-39. The full first line of the poem runs: "I saw the best minds of my generation destroyed by madness, starving, hysterical, naked, dragging themselves through the Negro streets at dawn looking for an angry fix." (from Howl and Other Poems [1956]).

56 Hayden, supra n.46, at 39. See also David J. Danelski, "The Chicago Conspiracy Trial", in Political Trials, ed. Theodore L. Becker (New York: Bobbs-Merrill, 1971), 166. 
emphasize the bizarre. Even the straightest reporter will communicate chaos because it sells. The Yippies know this because their politics involve consciously marketing themselves as mythic personality models for kids." 57 And in fact defendants Hoffman and Rubin spent much of their courtroom time analyzing trial coverage by the media: plotting press conferences, arranging for Yippie witnesses to get on the stand in time for the deadlines - what we all recognize today as the art of spin control. 58

In short, the Chicago 7 trial became a spectacle in which defendants and their attorneys deliberately drew upon popular cultural stories and images for internal and external consumption - to goad the trial judge and to persuade the jury and the public at large that the forces of playfulness and life-affirmation were on trial against forces of fear and repression. What we see here are defendants, particularly Abbie Hoffman and Jerry Rubin, manipulating reality, much like Pulp Fiction director Quentin Tarrantino, by shrewdly playing off of popular cultural iconography. The defendants internalized pop cultural constructs precisely in order to project back into the public domain specific countercultural ideals, symbols, and rhetoric. Their objective was to simultaneously enhance their own popularity, as media celebrities, and to cultivate the support necessary for their exoneration at trial.

57 Tom Hayden, supra n.46, at 69 ("For Abbie and Jerry ... the courtroom was a new theatre, perhaps a purer kind of theatre than anything in previous Yippie [Youth International Party] history.").

58 See Hayden, ibid.: "Now almost entirely media personalities, Abbie and Jerry would spend much of their courtroom time analyzing coverage in the papers ... and even calculating which of the defendants was getting most of the media attention."

Abbie Hoffman's understanding of the mass media, and of the "politics of constructivism," was a sophisticated one. Consider, for example, this excerpt from his direct testimony at trial:

The term "myth" refers to an attitude, a subjective historical view of what is going on in society or in history past or history future. It is a subjective reality; the alliance between what actually happened and between thoughts and wonders and dreams and projections for the future is blurred together. For example, people's prejudices about what they see, since it is subjective, play a great role...

Every body participated in the Yippie myth and those people that participated most would be those people, newsmen and people in power who instantaneously can get on the news and hold press conferences and say whatever they want and have it absolutely reported. (Transcript at 375 ). 
This strategy may also have helped to provoke federal district judge Julius Hoffman into playing the role of strict and partial authoritarian, a role that the Seventh Circuit court explicitly condemned on appeal, in an opinion that overturned the defendants' convictions. 59

\section{The Randall Dale Adams Trial}

As in the Chicago 7 trial, Errol Morris's portrayal of the trial of Randall Dale Adams in his film, The Thin Blue Line, used mass media representations to reach into stock cultural scripts, story lines, and character types in order to play upon people's beliefs and expectations. The film consists mostly of interviews with the individuals who participated in the trial - the judge, the defence lawyers, and the witnesses who testified, including the defendant. In this respect, it was ostensibly a film documentary. However, throughout the film Morris introduces scenarios that undercut the film's documentary status. For example, Morris stages and repeatedly replays (a la Rashomon ${ }^{60}$ ) the scene of the shooting. In addition to this as well as other dramatic reenactments, all of which used actors instead of the real persons involved, Morris also overlays fictional film images on top of important film monologues spoken by the actual participants in the trial.

For example, consider the film's treatment of two players in the actual trial, Mrs. Emily Miller, a self-described eyewitness to the shooting, and Judge Don Metcalfe, the judge who presided over the trial. First, here is an excerpt from Mrs. Miller's film monologue:

MRS. MILLER: Yeah, when I was a kid I used to want to be a detective all the time because I used to watch all the detective shows on TV.

When I was a kid, they used to show these movies with Boston Blackie, and he always had a woman with him. And I wanted to be the wife of a detective or be a detective, so I always watched detective stories.

You know, it's always happening to me, everywhere I go, you know. Lots of times there's killings or anything, even around my house. Wherever. And I'm always looking or getting involved, you know. Find

\section{See United States v. Dellinger, 472 F. 2d 340 (7th Cir. 1972).}

60 Akira Kurosawa's film, Rashomon, depicts how the perception of reality is rooted in the perceiver's perspective. Kurosawa demonstrates the contingencies of interpretation by juxtaposing several re-enactments of a crime as seen from the vantage points of different eyewitnesses. Each version reflects the emotional make-up and character of the individual storyteller. 
out who did it, or what's going on.

I listen to people. And I'm always trying to decide who's lying, or who killed who before the police do; see if I can beat them. Yeah. ${ }^{61}$

Notably, as we watch Mrs. Miller's talking head the scene abruptly shifts. We still hear her voice, but in place of Mrs. Miller we see images from a grade $\mathrm{B}$, Boston Blackie television detective story. In the scene, we see a woman accompanying a gun-toting detective. She watches fearfully as he shoots the villain of the piece. The inference to be drawn from these stock images is clear. Morris is using this footage to comment on what Mrs. Miller is saying. The result is potent: we laugh. So this is Mrs. Miller's world, we say to ourselves. It is a mental reality lifted from the movies. ${ }^{62}$ Clearly, Mrs. Miller is living in a world of fantasies. She can no longer tell the difference between reality and fiction. ${ }^{63}$ In plain English, she's nuts.

Now consider the following excerpt from the film monologue by Judge Metcalfe:

JUDGE METCALFE: I grew up in a family where I was taught a great respect for law enforcement, and became acutely aware of the dangers that police officers go through, law enforcement officials go through, that I think much of the public is not really sensitive to.

My father was an FBI man probably at the worst possible time to be in the FBI. It was from 1932 to 1935 in Chicago. My father had been sent to a lodge in Wisconsin. A car drove up with four men in it. They all had on sunglasses, hats. Dad says, "Well, he's in town." And with that, Dad said, the car drove off, he realized it could possibly have been Baby Face Nelson.

My father told me that had he known it was Nelson, he would have

61 See The Thin Blue Line (Third Floor Productions, 1988), transcript at 27 (transcript on file with author).

62 The use of pop cultural reality to discredit a witness's credibility has been used effectively inside the courtroom. Consider, for example, a recently televised Scottish criminal trial in which the defence attorney discredited an eyewitness's account by suggesting to the jury that it sounded as if it came straight out of the classic Gary Cooper Western, High Noon. See The Trial (BBC Productions). (I am grateful to Suzanne Gibson for bringing to my attention this use of pop culture at trial.)

63 And, of course, Morris' deeper ("postmodern") message is: neither can we. See John Fiske, Media Matters (Minneapolis: University of Minnesota Press, 1994), xxii: "Like popular culture, the law, too, has lost any sense of a clear boundary between the representation and the real, between the public opinion of a mediated society and the rational opinion of a courtroom." 
pulled his gun, and that I would not be alive today - I wasn't born until several years later. ${ }^{64}$

Morris plays with Judge Metcalfe's monologue in the same way that he played with Mrs. Miller's. However, this time, instead of the stock cops and robbers scenario that introduced us to Mrs. Miller's weird "crimestopper's" mental landscape, we now see unfurling before our eyes one of those stock "G-man" (or FBI agent) scenarios that most Americans absorbed, whether as kids or adults, from countless television shows and movies. And again, hearing Judge Metcalfe's self-serving monologue about his dad's glory days in the Chicago FBI has a similarly powerful effect. As with Mrs. Miller, we laugh. Only now it is not at the judge's craziness, but rather at his blatant bias which we see in the form of his intense romanticization of, and concomitant sympathy for, federal and state law enforcement agents.

By triggering in our own heads the latent stereotypes, stock scripts and character types that appear to make up the judge's and Mrs. Miller's sense of reality, Morris reinforces one of the main points that his film is making, namely: that the crucial players in the Adams trial were utterly unreliable. We come to see that their sense of reality was made up of various and sundry false assumptions, distorted stereotypes, and other unreliable sources of knowledge about how things are in the world. ${ }^{65}$

Morris' documentary and subliminal docudrama techniques (i.e., his use of dramatic re-enactments and stock footage overlays) work. Most viewers of his film, including the Dallas Court officials who subsequently decided to reopen Adams's case, came away convinced. Adams is innocent. He was framed by a group of corrupt, crazed, ambitious, greedy, or otherwise biased characters who couldn't care less about outsider-types like Adams - a mere "drifter," in Judge Metcalfe's memorable phrase. ${ }^{66}$

By the time the film is over, we feel triumphant. It is the familiar rush that a good mystery story promises, and that it rewards us with in

The Thin Blue Line, transcript at 22-23.

65 The other point that Morris is making, a far more subversive one, is that it is by virtue of these stock images and story lines that all of us make up the worlds we live in. Judge Metcalfe and Mrs. Miller are not unique in this respect. It is this feature of Morris' film that makes the general public's, and most critics', treatment of the film as a "documentary" so oddly mistaken.

66 The Thin Blue Line, transcript at 22. 
the end. "Now we know the truth." And indeed, after the film's release, in the glare of intense media scrutiny, Adams's conviction was thrown out. After twelve and a half years in prison, Adams walked free. The innocent scapegoat of a corrupt Dallas frame-up. We feel good. Truth and justice have triumphed in the end.

But it is not on that triumphant note that I want to leave things.

I want to spoil the fun because I think there is a danger in such optimism. For one thing, it is naive. And in any event, it is beside the point. For even as we glory in Morris' expose of injustice, I think we are still caught up in - we are still unreflectively playing out - the particular truths that this particular story genre allows.

With this in mind, consider one more excerpt from the film, this time from a monologue by yet another self-described eyewitness to the shooting, Michael Randell:

MICHAEL RANDELL: I'm a salesman and you develop something like total recall. I don't forget places, and things, or streets, because it's a habit. Something I just picked up. I just stare intensely at people and try to figure them out.

I was leaving the Plush Pub one night, driving a 1977 Cadillac, heading west on Hampton, I noticed a officer had two individuals pulled over to the curb in a blue some type of vehicle. It was ... it was a blue ... it was a blue ... I think ... it was a blue Ford. It was a blue something.

The driver, I think, had long blonde hair and a mustache. And the other didn't have no hairs on his face.

And at certain times of the night you do not go through there, because you're gonna get stopped. A person that's white going through that area at night - he's a sore thumb to stick out for the first reason. And if they don't look right, they're gonna stop you. That's ... that's bottom line. I could go through there; if I lean in my seat the wrong way, I'm getting pulled over.

The officer, he walked up to the vehicle. He had walked up. His car was ... let me see ... I don't know if it was behind or in front, but I know he had him pulled over, and he was up to the car. Let me think. Yeah, he was up to the car. He had to have been up to the car. He was up to the car. I didn't see no bullet. I didn't see no gunfire. Because I went on. ${ }^{67}$

First, consider why we know, even from this brief excerpt, why Michael Randell is a liar. The basis for our knowledge consists in its social constructedness and (as in Pulp Fiction) our simultaneous awareness of the construction. Begin with the familiar cultural maxim: 
everyone knows that inconsistency bespeaks falsity. ${ }^{68}$ Randell starts out by telling a personal myth, and we immediately see through it. He says, "I don't forget." But of course he does: "I noticed some type of vehicle ... it was ... it was a blue ... It was a blue something ..."

We even seem to see how Randell goes about deceiving us, and perhaps even himself: "He was up to the car. Let me think. Yeah, he was up to the car. He had to have been up to the car. He was up to the car."

Second, we also see how Randell's identity and social status frame his sense of truth and justice. For one thing, Randell clearly is an outsider, subject to arbitrary police power: "They're gonna stop you ... That's the bottom line ... If I lean in my seat the wrong way I'm getting pulled over."

Finally, race is a significant factor in Randell's understanding of how the world works.: "A person that's white going through that area at night - [West Dallas, where the shooting occurred, is an all black neighbourhood] - he's a sore thumb ... They're gonna stop you ..."

Thus, Randell's story comes to this:

- arbitrary police power rules;

- outsiders are targets;

- Adams, and his sixteen year old companion in the car at the time of the shooting, were bound to be stopped given who and where they were on the night in question.

What Morris is doing here, and what he does throughout The Thin Blue Line, is show us how people's pre-existing beliefs and expectations shape the way they see and talk about the world. In other words, he is showing us how meanings are socially and culturally constructed.

But Morris is also doing more. He is using our prejudices - we, the movie audience - to indict the prosecution, to show the state's frameup of Randall Dale Adams. And to do that, we must be seduced by the story of the defence.

It is an interesting thing. When we actually see how meanings are made, when we catch sight of the prejudices that were at work in the state's case against Adams, we are more prone to mistrust them, to condemn them as "distortion." Which is fine, except that in doing this we tend to forget the prejudices that make such a judgment possible in the first place. 
So, with this insight in mind, let us take the next step and ask: what beliefs and expectations make Morris' exposé possible? What if we were to see through Morris' story of the defence? If we spot the way it seduces will we then grow suspicious of the truths that it conjures in our minds? Will we then be tempted to seek out other truths, truths that Morris' story represses?

Let's see. Allow me to tell you the mystifying, untold tale of homosexuality denied. Call it: the story that Morris left on the cutting room floor. Consider these details:

- 27 year old Randall Dale Adams and 16 year old David Harris - perfect strangers until their chance meeting on a Dallas roadway - spend an entire day together;

- they drink beer together, smoke pot, hang out in a pool hall, go to a soft porn drive-in movie;

- Adams says he'll try to get Harris a job where Adams works;

- that night, when Adams asks his brother if young Harris can stay over at the motel where Adams and his brother are staying, the brother says he doesn't like that sort of thing.

What sort of thing?

After Adams' brother says no, do Harris and Adams drive together onto Inman Road? Were they parked by the roadside with the car lights off when a police officer approached their car? What did the investiga ting officer see? Did Harris shoot because he had to violently suppress the meaning of a roadside homosexual encounter? Did Adams? Was killing the witness to that scene the only way to make it go away? The only way for Harris or Adams to repress a feared (or is it a real) homosexual identity?

If believed, the story of Adams' and Harris' homosexuality invites us to mistrust the certainty that Morris' mystery expose induces. Was Adams the innocent victim that Morris portrays? Or was he an accomplice to murder? Or perhaps even the murderer?

We don't know.

My point is this: it is only by breaking free of the beliefs and expectations that Morris' mystery-exposé genre takes for granted that we can know that we don't know. Only when we spot and suspend the narrative necessity of a particular story can we entertain the possibility of other stories, and of other truths.

I will sum up with this. In the story / counter-story dynamic of criminal trials, lawyers need to keep two meaning making strategies in 
mind: (1) the strategy of narrative seduction (e.g., using such techniques as self-dramatization and mythification through mass media representations), and (2) the strategy of disbelief (e.g., surfacing into the light of critical reflection the mind's genre-frozen assumptions - about stock story forms, scenarios, and character types - as well as its defences against unfamiliar or subjectively disturbing truths).

The art and the craft of legal storytelling lie in the details of story and context. As legal scholars, that is where we should be looking. 